гтраданін отець или мать; эти данныл, замьчаеть авторь,

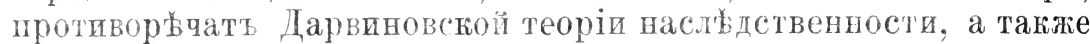
теоріш шерекрестной насльдственности.

\title{
I. X.
}

D. Stewart: The Increase of general Paralysis in Fingland and Wales: its Causation and Significance. (The journal of mental science. 1896, № 143).

Вь Авгліи и Валлись⿱㇒㠯 за $1881-1891$ гг. количестьо вародоваселенія увеличцлось на $11,7 \%$, тогда какж случаи психпческаго помбшательства- на $15,24^{\circ} / 0$. Надолю обцаго прогрессивнаго шаралича прпходится $9 \%$ всего количества больныхь, поступишихь въ психіатрическія лечебницы Англіи и Валписа. За 15 л. (1878-1892 гг.) количество паралитиковт было 18,438, составляя 8\% всего поличества больныхт вт

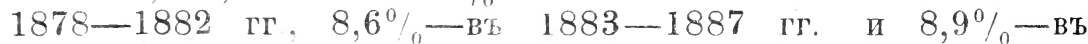
$1888-1892$ rr.

Мужчины въ течевіи посльдняо пятильтія забольвани вь 19 разь чапе женщинь; зажғточные п обезнеченные слои общества-вдвое qаще бьдняковъ, среди которыхт случаи прогрессивнаго паралича, по мьр⿱宀㠯 наростанія посльдняго среди

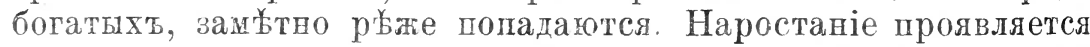
больше всего въ молодомь, цвьтүщемь возрасть (35-44 гг.)

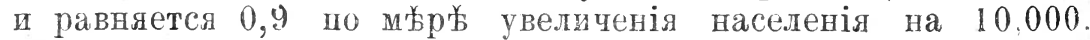
ن̈енатые вь 5 разє чаще поражаются холостыхн, а замужніявъ 60 разь чаще незамужнихє; такь вь $1878-1882$ гг。 сь наростаніемт, вародонаселенія на 10,000 челов'ьћ, количество прогрессивныхь паралитиковь среди холостыхь наростало на 3,5. а среди женатыхь на 6,0; въ 1888 - 1892 наростаніе среди первыхь равнялось 3,7 , а среди посльднихь-6,2. Наростаніе прогрессивных' паралитиковь преимущественно проявляется в'ь обширныхь многолюдныхт центрах' -приморскихь. мануфактурныхь; вь деревняхь, селахъ-уменьшеніе. Причины- 1) алкоголизм, 2) венерическія бользни (сифились). 3) половыя излишества.

Выводъ: постепенное наростаніе прогрессивниго пара лича пом'шанныхь указываеть на преждевременное вымираніе-физическое и нравственное-надік. 